\title{
The cysts of Ceratium hirundinella: Their dynamics and role within a eutrophic (Lake Sempach, Switzerland)
}

\author{
U. Pollingher ${ }^{1}$, H. R. Bürgi ${ }^{2}$ und H. Ambühl ${ }^{2}$ \\ 1 Israel Oceanographic and Limnological Research Tel-Shikmona, P.O.B. 8030, Haifa 31080, \\ Israel \\ 2 Institute of Aquatic Sciences and Water Pollution Control (EAWAG), CH-8600 Dübendorf, \\ Switzerland
}

Key words: Ceratium, Peridinium, water bloom, cysts, abundance, distribution, sediments, survival, nutrients.

\begin{abstract}
The dynamics of the Ceratium hirundinella population and the abundance of dinocysts in the plankton and sediments were studied in Lake Sempach in 1988. In 1987, a rich population of

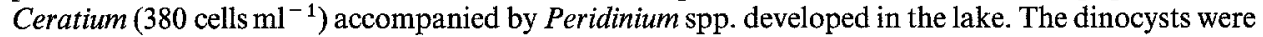
found entrapped in a kind of flocs, in the deepest part of the lake, in the upper flocculent layer. The number of viable cysts of Ceratium in the sediments decreased gradually from April to July 1988 . The Ceratium population increased slowly starting in April, and reached a maximum number in August ( 31 cells $\mathrm{ml}^{-1}$ ). Peridinium willei reached 100 cells $\mathrm{ml}^{-1}$. Newly formed cysts of Ceratium were recorded in the plankton and sediments at the end of July - beginning of August. They appear in the sediments as separate cells. Their number increased gradually, reaching a maximum of $600 \mathrm{cysts}^{-1}$ at the end of October. Ceratium formed more cysts than did Peridinium, but the rate of survival of the Ceratium cysts appears to be lower than that of Peridinium cysts. In addition to their biological functions, the cysts also have an impact on the ecosystem as carriers of nutrients from down to up and from up to down.
\end{abstract}

\section{Introduction}

Dinoflagellates are common in lakes, ponds and man-made lakes or reservoirs. They are present in large lakes (surface area more than $500 \mathrm{~km}^{2}$ : Lakes Constance, Geneva, Superior, Victoria, etc.) (Pollingher, 1990), but form water blooms mainly in smaller, natural and man-made lakes (Pollingher, 1987).

The bloom-forming species belong to the genera Ceratium, Peridinium and Peridiniopsis.

In temperate zones the water blooms develop during the stratification period, when the concentration of nutrients is low, but the light and temperature are optimal. This is possible due to a series of ecophysiological strategies which the dinoflagellates have developed (Pollingher, 1988). Their life cycle allows them to inhabit the 
plankton as a motile vegetative cell when the environmental conditions are favorable, and to inhabit the benthos as a non-motile spore (cyst) when the environmental conditions become unfavorable for the vegetative cell.

In temperate zones the dinocyst is an overwintering form, whereas in subtropical Lake Kinneret the cysts of the same species are oversummering forms (Pollingher and Hickel, 1991).

Data on the abundance and distribution of freshwater cysts in plankton and recent sediments are scarce (Huber and Nipkow, 1923; Livingstone, 1979, 1984; Heaney et al., 1983).

The aim of the study is an attempt to elucidate the abundance and distribution of the Ceratium hirundinella cysts in the plankton and sediments, as well as the cysts' impact on the ecosystem.

Lake Sempach, of glacial origin, located in central Switzerland, was chosen for this purpose.

\section{Background and methods}

Lake Sempach has a surface area of $14.4 \mathrm{~km}^{2}$ and a maximum and mean depth of 87 and $46 \mathrm{~m}$, respectively (Weilenman et al., 1989). The lake is stratified from mid April to mid September. The depth of the epilimnion varies between $5 \mathrm{~m}$ (April) to $12.5 \mathrm{~m}$ (November). The temperature of the water varies between $2-5^{\circ} \mathrm{C}$ in winter, and starts to increase in the epilimnion in April, reaching $20-24^{\circ} \mathrm{C}$ in July-August. The temperature of the water near the bottom remains very low $\left(3.5-5^{\circ} \mathrm{C}\right)$ throughout the year.

In the seventies, the phytoplankton was dominated by dinoflagellates and cryptophytes. In 1975, a heavy water bloom of dinoflagellates developed (Bürgi and Stadelmann, 1991). Ceratium hirundinella reached an abundance of $380 \mathrm{cells} \mathrm{ml}^{-1}$ in the epilimnion $(0-10 \mathrm{~m})$, when the phosphate level (SRP) was below $1 \mathrm{mg} \mathrm{m}^{-3}$, and the ammonia/nitrate level was below $20-130 \mathrm{mg} \mathrm{m}^{-3}$ during the whole period of Ceratium development. With the enhancement of the Ceratium biomass, the content of particulate nitrogen and phosphorus increased from 160 to $1020 \mathrm{mg} \mathrm{m}^{-3}$ and from 15 to $59 \mathrm{mg} \mathrm{m}^{-3}$, respectively. This corresponds to an input of about 5 tons of phosphorus to the whole lake within one month.

The annual average of phytoplankton biomass was $38 \mathrm{~g} \mathrm{~m}^{-2}$ wet weight. Due to a progressive enrichment with nutrients, the lake reached highly eutrophic conditions in 1982, and changes in the phytoplankton composition occurred: dominance of nitrogen-fixing cyanophytes (Bürgi and Stadelmann, 1991).

Since 1984 the lake has been artificially destratified in winter by aeration and supplied with pure oxygen in summer in order to prevent anoxic conditions in the hypolimnion and to reduce the cycling of phosphorus (Stadelmann, 1988). The water is of the calcium carbonate type. The concentrations of nitrate and soluble reactive phosphorus (SRP) are high in winter: 800 and $120 \mathrm{mg} \mathrm{m}^{-3}$, respectively. Their concentrations decrease in the epilimnion in summer-fall (June-November 1988: $\mathrm{NO}_{3} 20-40 \mathrm{mg} \mathrm{m}^{-3}$ and SPR $1 \mathrm{mg} \mathrm{m}^{-3}$, Ambühl, unpublished data). The annual average of primary production is $400 \mathrm{~g} \mathrm{C} \mathrm{m}^{-2} \mathrm{y}^{-1}$ (Stadelmann, 1988). 
Weekly sampling of plankton and sediments was carried out from the end of April to December 1988, at the deepest part of the lake (depth $83 \mathrm{~m}$ ). Sediment samples were also taken from the littoral and at 30 and $60 \mathrm{~m}$ depth. Samples were collected with the gravity corer designed and described by Ambühl (1985). The cysts' abundance was followed in the plankton samples, in samples from two traps (built according to Bloesch and Burns, 1980) exposed at the base of the epilimnion (13 m) for seven days, and in the sediment samples. The cysts entrapped in flocs were separated by sonication. The cysts from the plankton, from the traps and from the sediments were counted using an inverted microscope and the Utermöhl (1958) sedimentation method.

The presence of microgranular cytoplasm in Brownian motion was used as a sign of positive viability (Anderson and Wall, 1978). The viability of the cysts was also tested by inducing excystation. The results obtained are expressed as follows: the cysts in the water as number per $\mathrm{ml}$ or liter, those from the traps as number per $\mathrm{cm}^{2}$, those from the sediments as number per gram wet weight (gww), and the vegetative cells as numbers per $\mathrm{ml}$ or liter.

\section{Results and discussion}

In Lake Sempach in recent years, with the decrease of nutrients, a shift in the phytoplankton composition occurred. In summer 1987, a rich population of Ceratium hirundinella developed in the lake. Ceratium was accompanied by Peridinium willei and P. aciculiferum. The phytoplankton biomass decreased to an annual average of $26 \mathrm{gww} \mathrm{m}^{-2}$ (Bürgi and Stadelmann, 1991).

Dinoflagellate encystment, which generally happens at the end of the bloom, occurred between the end of September and the beginning of October. Then, 100 vegetative cells $\mathrm{ml}^{-1}$ and 7 cysts $\mathrm{ml}^{-1}$ of Ceratium were recorded (Bürgi, unpublished data). With the formation of the cyst, the settling velocity of the particle increased from $0.07 \mathrm{~m} \mathrm{day}^{-1}$ as a flagellate cell to about $6-10 \mathrm{~m} \mathrm{day}^{-1}$ as a cyst (the settling velocity was calculated according to sedimentation measurements in Lake Constance by Stabel, 1986). The cysts remain in the sediments until spring of the following year, when they are ready to germinate and may constitute the inoculum of the summer water bloom.

At the end of April 1988, very young cells of Ceratium and Peridinium as well as empty cysts were observed in the water. At the same time, we started the survey of cysts' abundance in the sediments. Cysts were found only in the deepest part of the lake ( 68 and $83 \mathrm{~m})$. At the littoral, only a few viable cysts of Ceratium and Peridinium were discovered.

Although the cysts are produced in the epilimnion all over the lake, they were found only in its deepest part. This is probably due to the fact that the sediments in shallow waters are stirred and resuspended more frequently and more extensively than the sediments in deep water. As a result of repeated resuspension, followed by redeposition over the entire basin, the fine material is moved from shallow to deep water (Davis, 1968). The remaining cysts in shallow water are the first ones which are resuspended and excysted (Pollingher and Hickel, 1991). Therefore there were no 
Table 1. Density of cysts within the sediments ( $\mathrm{nrg}^{-1} \mathrm{w} . \mathrm{w}$ )

\begin{tabular}{ll}
\hline Date of sampling & Cysts \\
\hline 11 May 1988 & 8500 cysts Ceratium \\
& 20 cysts Peridinium \\
22 June 1988 & 732 cysts Ceratium \\
13 July 1988 & 250 cysts Ceratium \\
& 10 cysts Peridinium \\
20 July 1988 & The majority are dead and empty cysts. \\
& Viable cysts still present. \\
3 August 1988 & 5000 newly formed cysts Ceratium \\
& 25 cysts Peridinium \\
& 15 excysted cells of Peridinium \\
16 August 1988 & 20250 cysts Ceratium \\
& 160 cysts Peridinium \\
End March 1989 & 285 mature cysts Ceratium \\
The sample of 16 August & 130 cysts Peridinium \\
1988 kept in the laboratory & 1150 viable cysts Ceratium \\
5 April 1989 & 80 cysts Peridinium \\
Lake sediment sample & Germination of Ceratium \\
10 April 1989 & and Peridinium in the laboratory \\
\hline
\end{tabular}

more in the littoral sediments when the investigations started, but empty cysts of Ceratium were found.

In the flocculent layer of the sediments sampled at the deepest part of the lake in May, 8500 viable cysts of Ceratium and 20 cysts of Peridinium per gww were counted (Table 1). In June, the number of viable cysts of Ceratium decreased drastically to 732 cysts gww $^{-1}$ and in July, only 250 cysts of Ceratium and 10 of Peridinium per gww were found. The number of dead and empty cysts increased. The dead and the empty cysts remained in the flocculent layer as large flocs on which photosynthetic algae and calcite crystals were deposited.

The year 1988 was characterized by a mild winter and a warm spring. The succession of the planktonic algae started earlier than in the preceding year, and a water bloom of the green alga Staurastrum developed during the summer-fall. Peridinium willei was more abundant than Ceratium, reaching 100 cells ml$^{-1}$ in July. C. hirundinella, which was recorded at the beginning of April, increased slowly, reaching its peak of 31000 cells $1^{-1}$ at the beginning of August when the number of Peridinium decreased. Thus, Ceratium did not form a bloom in summer 1988. The growth curve of Ceratium (Fig. 1) shows a long exponential phase, a very short stationary phase and a drastic two-step decrease in the population. The first decline occurred in August (temperature $23.08^{\circ} \mathrm{C}$ ) when the number of vegetative cells decreased from 31000 to 5000 cells $1^{-1}$, and the number of newly formed cysts in the water increased to 221 cells $1^{-1}$. The first newly formed cysts were recorded at the end of July. The vegetative cells remained for a relatively long period at about 


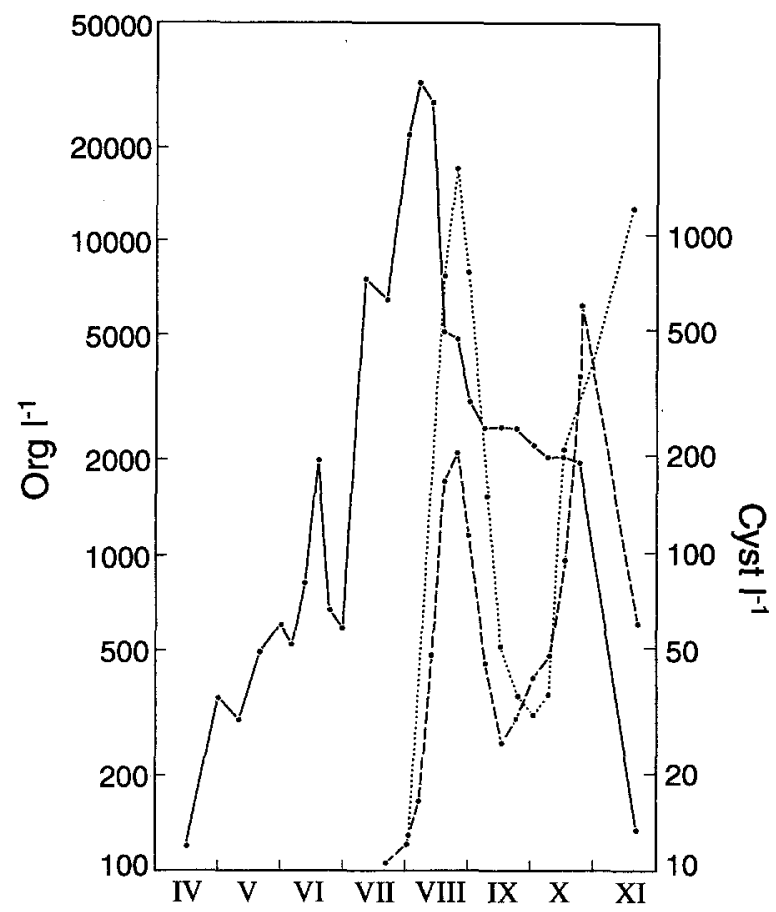

Figure 1. Ceratium hirundinella; abundance of vegetative cells (full line), abundance of casts in the water (broken line), abundance of cysts in the traps (dotted line)

2000 cells $1^{-1}$, decreasing in October $\left(13.6^{\circ} \mathrm{C}\right)$ and disappearing in November $\left(9^{\circ} \mathrm{C}\right)$. The number of cysts in October reached $6001^{-1}$ (Fig. 1).

A reasonably good correspondence was found between the abundance of cysts in the plankton and in the traps (Fig. 1). During the first peak of cyst formation, 1636 cysts $\mathrm{cm}^{-2}$ were recorded, and during the second one, $1236 \mathrm{cysts} \mathrm{cm}^{-2}$ were counted in the traps.

The newly formed cysts were recorded in the sediments at the beginning of August. Those cysts did not appear in flocs, and in optical microscopy they appear different from the dormant ones. They have a brownish coloration. They contain lipid or starch reserves with little or no visible microgranular cytoplasm in Brownian movement. Five thousand cysts of Ceratium and 25 of Peridinium per gww were recorded. After two weeks, the number of cysts of Ceratium increased to 20250 and that of Peridinium to 160 per gww. Although the population of Ceratium was smaller than that of Peridinium, it produced higher numbers of cysts, i.e. a high percentage of the population is transformed into cysts. Observations over many years indicate that in Esthwaite water (England) (surface area $1 \mathrm{~km}^{2}$ ), most cells of the Ceratium population often encyst during September and October. In 1981, only $10 \%$ of the population encysted and in 1980 normal encystment was not observed (Heaney et al., 1983). Mass encystment of C. hirundinella was also described in Lake Vechten (Netherlands) (Steenbergen, 1982). Reynolds (1984), studying the recovery of cysts of 
C. hirundinella in Lund Tubes, suggested that they represent $35-42 \%$ of the maximum crop of vegetative cells. Heaney et al. (1983) took into account that most of the population encysted, and calculated that the deposition to the sediment could be as high a 200000 cysts $\mathrm{cm}^{-2}$. Livingstone (1979) counted the cysts in the sediments near the deepest part of the lake in 1977 and 1978 and found in the upper $1 \mathrm{~cm}$ layer about 300000 and $70000 \mathrm{~cm}^{-2}$, respectively, at the beginning of November. In 1981, when only about $10 \%$ of the population encysted, an average density of $21000 \mathrm{cysts} \mathrm{cm}^{-2}$ was found (Heaney et al., 1983). The number of cysts found in Lake Sempach in November was $5419 \mathrm{~cm}^{-2}$ in the upper $1 \mathrm{~cm}$ layer of the sediment in the deepest part of the basin.

The cysts formed in August-October will excyst only in April-June of the following year. Thus Ceratium spends more time as a cyst than as a vegetative cell.

The sediment samples taken in August 1988 were kept in the laboratory in the dark at a temperature similar to that on the bottom of the lake $\left(4-5^{\circ} \mathrm{C}\right)$ and screened at the end of March 1989. The results obtained were 285 mature cysts of Ceratium per gww (survival only $1.4 \%$ ) and 130 cysts of Peridinium per gww (survival $81 \%$ ). A similar situation occurred also in other samples kept in the laboratory. In a sediment sample from the lake taken at the same time (1989), there were 1150 cysts of Ceratium per gww (survival $5.7 \%$ ) and 80 cysts of Peridinium per gww (survival $50 \%$ ). At this time in water, Ceratium and Peridinium were absent. In both cases, after 5 days, cysts of Ceratium and Peridinium excysted in the laboratory, and young Ceratia were recorded. Peridinium appeared as young cells which still had both eyespots, and some young cells even built up the theca. These results suggest that the cysts' mortality rate is very high. Pollingher and Serruya (1976) have shown that even a small inoculum (cysts) is sufficient to produce the bloom of $P$. gatunense in Lake Kinneret. Heaney et al. (1983) remarked that the germination of relatively few cysts is enough for the development of the Ceratium water bloom in Esthwaite water.

Studies on C. hirundinella cysts by Huber and Nipkow $(1922,1923)$ have shown that changes in temperature are of major importance in stimulating excystation. In lakes located in the temperate zone, the cysts of $C$. hirundinella germinate (excyst) when the temperature increases (Huber and Nipkow, 1922, 1923; Heaney et al., 1983), whereas in subtropical Lake Kinneret, excystation occurs when the temperature decreases. The development of the vegetative cells occurs at about the same temperature ranges in Lake Kinneret and in temperate lakes. It occurs in spring in Lake Kinneret and in summer-fall in temperate lakes. C. hirundinella in Lake Kinneret disappears when the temperature of the water increases above $25^{\circ} \mathrm{C}$. The highest rate of cyst formation (encystation) is recorded at the end of the water bloom. The cyst of C. hirundinella is an overwintering form in temperate lakes and an oversummering form in warm Lake Kinneret (Pollingher and Hickel, 1991).

Nutrient limitation is generally implicated as the encystment stimulus in laboratory studies (Pfiester, 1976, 1977; Anderson et al., 1983, 1984).

Anderson and Wall (1978), studying the importance of benthic cysts in initiating the water bloom of toxic dinoflagellates, concluded that excystment, once initiated, generally proceeds regardless of the suitability of the ambient environment, whereas cell division is dependent on the presence of suitable light and chelators. Pollingher and Zemel (1981) have shown that high turbulence generated by wind (speed 
$>3.5 \mathrm{~m} \mathrm{~s}^{-1}$ ) has a negative effect on the division of $P$. gatunense. Thus the timing of the bloom development and its magnitude are a function of the duration and intensity of the mixing period.

Since the newly formed cysts reach the sediments as single cells and are not entrapped in flocs, the question which arises is: when, where and how does this process occur? It does not occur during the sedimentation, which is very fast $\left(10 \mathrm{~m} \mathrm{day}^{-1}\right)$. It may occur during the periods of dislocation, transportation and redeposition or within the sediments.

Four biological functions have been attributed to marine dinocysts: reproduction, protection, propagation and dispersion (Wall, 1971). They are also the functions of freshwater cysts.

The freshwater cysts, surviving or not, also have an impact on the ecosystem. The cysts are relatively large particles. The cyst of Ceratium has a length of $40 \mu \mathrm{m}$ and a width of $30-45 \mu \mathrm{m}$, whereas that of Peridinium has a diameter of $35-45 \mu \mathrm{m}$.

Taking into account the chemical composition of Ceratium according to Heaney et al. (1986), the phosphorus incorporated in the cysts which reached the sediments was calculated. It represented $23 \mathrm{~kg}$ particulate phosphorus in 1988, a year when Ceratium did not form a bloom. The phosphorus incorporated and transported to the epilimnion by the germinated cysts, together with the phosphorus accumulated by the vegetative cells by luxury consumption, may reach $115 \mathrm{~kg}$.

In a "Ceratium year", the number of cysts produced is much higher (Livingstone, 1979), and the quantity of transported phosphorus by the cysts and accumulated by the vegetative cells may be 5 or more times higher. Regarding the changes of concentration of particulate phosphorus in the epilimnion of Lake Sempach in 1975 (increase of about $350 \mathrm{~kg} \mathrm{P} \mathrm{km}^{-2}$, corresponding to more than $300 \%$ of the initial phosphorus concentration) during the period of the Ceratium bloom in September, the transport capacity of cysts or vegetative cells should not be neglected. It is worth mentioning that the decomposition of the dinoflagellate vegetative cells occurs rapidly in the epilimnion.

Large amounts of starch and lipids are stored within the cysts of Ceratium (Chapman et al., 1982). Lipids are also found in cysts of Peridinium. At the decomposition of the cysts, the lipid globules (drops) remain in the sediments and are ingested by benthic protozoa.

The dinoflagellates are important contributors of lipids to underlying bottom sediments in Lake Kinneret and in water bodies with a bloom of Ceratium (in Great Britain) (Robinson et al., 1984, 1986). Biological particles play an important role in removing trace metals $(\mathrm{Cu}, \mathrm{Zn})$ from the water column and in regulating their concentration (Stumm, 1987).

The cysts formed in the epilimnion sink down and the following year part of them return to the upper layers as vegetative cells. Those cells bring up nutrients which they have stored by "luxury consumption" at the mud-water interface. Thus at the beginning of the bloom their development does not depend on the nutrient concentrations in the epilimnion. The cysts which do not return to the epilimnion are decomposed and the nutrients are relased to the sediments. Thus the cyst is a carrier of nutrients in both directions, from down to up, and from up to down. 


\section{ACKNOWLEDGEMENTS}

The research was performed during a sabbatical leave of the first author at the Department of Limnology at the EAWAG.

The authors acknowledge the competent assistance of the departmental technical staff in the field work and in the laboratory. We thank also Dr. P. Stadelmann, Kt. Lucerne, for kind support with field equipment. Thanks are due to Ms. K. Diskin for typing the manuscript.

\section{REFERENCES}

Ambühl, H., 1985. Technik der Präparation und Darstellung von Sediment Kernen mit grossem Querschnitt. Schweiz. Z. Hydrol. 47:249-256.

Anderson, D. M. and D. Wall, 1978. Potential importance of benthic cysts of Gonyaulax tamarensis and Gonyaulax excavata in initiating toxic dinoflagellate blooms. J. Phycol. 14:224-234.

Anderson, D. M., S. W. Chisholm and C. J. Watras, 1983. Importance of life cycle events in the population dynamics of Gonyaulax tamarensis. Mar. Biol. 76:179-189.

Anderson, D. M., D. M. Kulis and B. J. Binder, 1984. Sexuality and cyst formation in the dinoflagellate Gonyaulax tamarensis: cyst yield in batch cultures. J. Phycol. 20:418 -425.

Bloesch, J. and N. M. Burns, 1980. A critical review of sedimentation trap technique. Schweiz. Z. Hydrol. 42:15-55.

Bürgi, H. R. and P. Stadelmann, 1991. Plankton succession in Lake Sempach, Lake Hallwil and Lake Baldeggo before and during internal restoration measures. Verh. Int. Verein. Limnol. 24:931936.

Chapman, D. V., J. D. Dodge and S. J. Heaney, 1982. Cyst formation in the freshwater dinoflagellate Ceratium hirundinella (Dinophyceae). J. Phycol. 18:121-129.

Davis, M. B., 1968. Pollen grains in lake sediments: redeposition caused by seasonal water circulation. Science 162:93-94.

Heaney, S. J., D. V. Chapman and H. R. Morison, 1983. The role of the cyst stage in the seasonal growth of the dinoflagellate Ceratium hirundinella within a small productive lake. Br. Phycol. J. $18: 47-59$.

Heaney, S. J., W. J. P. Smyly and J. F. Talling, 1986. Interactions of physical, chemical and biological processes in depth and time within a productive English lake during summer stratification. Int. Revue ges. Hydrobiol. $71: 441-494$.

Huber, G. and F. Nipkow, 1922. Experimentelle Untersuchungen über die Entwicklung von Ceratium hirundinella O.F.M. Z. Bot. 14:337-371.

Huber, G. and F. Nipkow, 1923. Experimentelle Untersuchungen über Entwicklung und Formbildung von Ceratium hirundinella O. F. Muller. Flora 116:114-215.

Livingstone, D., 1979. Algal remains in recent lake sediments. Ph. D. Thesis, University of Leicester [cited by Heaney et al., 1983].

Livingstone, D., 1984. The preservation of algal remains in recent lake sediments. In: Haworth, E. Y. and J. W. G. Lund (eds.), Lake Sediments and Environmental History. Leicester Univ. Press, pp. $191-202$.

Pfiester, L. A., 1976. Sexual reproduction of Peridinium willei (Dinophyceae). J. Phycol. 11:259-265.

Pfiester, L. A., 1977. Sexual reproduction of Peridinium gatunense (Dinophyceae). J. Phycol. 13: 92-95.

Pollingher, U., 1987. Ecology of dinoflagellates. In: Taylor, F. J. R. (ed.), The Biology of Dinoflagellates. B. Freshwater Ecosystems. Botanical Monographs 21. Oxford: Blackwell, pp. 502-529.

Pollingher, U., 1988. Freshwater armored dinoflagellates: growth, reproduction strategies and population dynamics. In: Sandgren, C. (ed.), Growth and Reproduction Strategies of Freshwater Phytoplankton. Cambridge: Cambridge Press, pp. 134-174.

Pollingher, U., 1990. Effect of latitude on phytoplankton composition and abundance in large lakes. In: Tilzer, M. and C. Serruya (eds.), Ecological Structure and Function in Large Lakes. Springer Verlag, pp. $368-402$. 
Pollingher, U. and B. Hickel, 1991. Dinoflagellate associations in a subtropical lake (Lake Kinneret, Israel). Arch. Hydrobiol. 120:267-285.

Pollingher, U. and C. Serruya, 1976. Phased division of Peridinium cinctum fa westii and the development of the bloom in Lake Kinneret (Israel). J. Phycol. 12:162-170.

Pollingher, U. and E. Zemel, 1981. In situ and experimental evidence of the influence of turbulence on cell division processes of Peridinium cinctum fa. westii (Lemm.) Lefevre. Br. Phycol. J. 16:281287.

Reynolds, C. S., 1984. The Ecology of Freshwater Phytoplankton. Cambridge: Cambridge University Press.

Robinson, N., G. Eglinton, S. C. Brassell and P. A. Cranwell, 1984. Dinoflagellate origin for sedimentary $4 \alpha$-methylsteroids and $5 \alpha(\mathrm{H})$ stanols. Nature 308:439-441.

Robinson, N., P. A. Cranwell, G. Eglinton, S. C. Brassell, C. L. Sharp, M. Gophen and U. Pollingher, 1986. Lipid geochemistry of Lake Kinneret. Org. Geochem. 10:733-742.

Stabel, H. H., 1986. Calcite precipitation in Lake Constance: chemical equilibrium, sedimentation and nucleation by algae. Limnol. Oceanogr. 31:1081-1093.

Stadelmann, P., 1988. Der Zustand des Sempachersees. Wasser, Energie, Luft 3/4:81-96.

Steenbergen, C. L. M., 1982. Phytoplankton periodicity and sediment trap recoveries. Prog. Rep., Limnol. Inst., Nieuwersluis, pp. 33-35.

Stumm, W., 1987. Aquatic Surface Chemistry. Wiley-Interscience.

Utermöhl, H., 1958. Zur Vervollkommnung der quantitativen Phytoplanktonmethodik. Mitt. Int. Ver. Limnol. 9:1-38.

Wall, D., 1971. Biological problems concerning fossilizable dinoflagellates. Geosci. Man. 3:1-15.

Weilenman, U., C. R. O'Melia and W. Stumm, 1989. Particle transport in lakes: models and measurements. Limnol. Oceanogr. 34:1-18.

Received 14 July 1992;

revised manuscript accepted 21 October 1992. 